\title{
Investigating the effect of packaging design on persuading consumers
}

\author{
Naser Azad, Samiyeh Bandad and Somayeh Hozouri*
}

Department of Management, South Tehran Branch, Islamic Azad University, Tehran, Iran

\begin{tabular}{l}
\hline C H R O N I C L E \\
\hline Article history: \\
Received September 10, 2013 \\
Received in revised format \\
10 December 2013 \\
Accepted December 122013 \\
Available online \\
December 162013 \\
\hline Keywords: \\
Factor analysis \\
Packaging design \\
Product development \\
\hline
\end{tabular}
A B S T R A C T

\begin{abstract}
This paper presents an investigation on the role of packaging design on persuading consumer to buy different products in city of Tehran, Iran. The proposed study designs a questionnaire in Likert scale consists of 26 questions, distributes it among some Iranian experts and analyzes it based on principal component analysis. During the survey, the number of questions is reduced from 26to 23. Cronbach alpha is calculated as 0.88 and Kaiser-Meyer-Olkin Measure of Sampling Adequacy and Approx. Chi-Square are 0.80 and 1880, respectively. Based on the results of our survey, we have derived five factors including requirement attributes, proportionality components, consumer choice, product appearance attractiveness and consumer characteristics.
\end{abstract}

(C) 2014 Growing Science Ltd. All rights reserved.

\section{Introduction}

Packaging plays essential role on promoting products, product development and there are many studies on how to promote different types of products and services through appropriate packaging (Reimann et al., 2010). According to Giese et al. (2013), key design properties of marketing artifacts that influence consumer response include perceived attractiveness. The packaging design normally adds value to a product, which has major impact on customers' purchasing decision process especially during the purchase event. However, most entrepreneurs do not have sufficient knowledge and skills regarding technology of packaging design. They face problems of choosing appropriate designs, which match with their products and services as well as packaging design systems. These problems may create time lost and an increment in production expenses. Auttarapong (2012) presented a decision support system in designing product packages where one will be able to specify product characteristics with its conditions such as graphic element and application aligned with the product package. To reach the corresponding expert system, design rules are extracted from the analysis of packaging design experts and customer's perception. Schoormans and Robben (1997) investigated the impact of the degree of deviation of coffee packages on consumers' attention and categorization. They reported that when redesigning stimuli in marketing practice, for example of products or packages, a trade-off had to be made between the high attention getting value of discrepant stimuli. According to Clement et al. (2013), it is widely recognized that the human brain

* Corresponding author. Tel.: +98 9125367924

E-mail addresses: saho84@rocketmail.com (S. Hozouri)

(C) 2014 Growing Science Ltd. All rights reserved. doi: $10.5267 /$ j.uscm.2013.12.003 
maintains limited capacity for perceptual stimuli and consumers' visual attention, when looking for a specific product or brand in a grocery store and examined the relationship between abundant in-store stimuli and limited human perceptual capacity. They examined the effect of package design features on visual attention by collecting the necessary data through two eye-tracking experiments, one in a grocery store based on wireless eye-tracking equipment, and another in a lab setting. They reported that consumers had fragmented visual attention during grocery shopping, and that their visual attention was simultaneously affected and disrupted by the shelf display. Physical design features such as shape and contrast dominated the initial phase of searching.

Çakır and Balagtas (2013) explained that it is common among producers of consumer packaged products to reduce the volume of product per package such that the new size replaces the old one named package downsizing. They investigated the extent to which consumers have various sensitivities to package price and package size in order to understand on the managerial implications of package downsizing. They estimated a random utility model of demand to measure consumer response to price and package size based on household scanner panel data on bulk ice cream purchases in Chicago. The main finding was that consumers were less responsive to package size than to price; the demand elasticity with respect to package size was approximately one-fourth the magnitude of the demand elasticity with respect to price. This result implied that marketing managers could apply downsizing as a hidden price increase to pass through increases in production costs, that is, the expenses of raw materials, and maintain, or increase, their profits.

\section{The proposed method}

This paper presents an investigation on the role of packaging design on persuading consumer in city of Tehran, Iran. The proposed study designs a questionnaire in Likert scale consists of 26 questions, distributes it among some Iranian experts and analyzes it based on principal component analysis. During the survey, the number of questions has been reduced to 23 because of existing skewness on some data. Cronbach alpha is calculated as 0.88 and Kaiser-Meyer-Olkin Measure of Sampling Adequacy and Approx. Chi-Square are 0.80 and 1880, respectively. Table 1 demonstrates the summary of communalities associated with the data. As we can observe from the results of our investigation, all data are well above 0.50 , which validates the quality of the data.

\section{Table 1}

The summary of communalities

\begin{tabular}{lll}
\hline & Initial & Extraction \\
\hline VAR00001 & 1.000 & .572 \\
VAR00002 & 1.000 & .386 \\
VAR00003 & 1.000 & .758 \\
VAR00005 & 1.000 & .766 \\
VAR00006 & 1.000 & .544 \\
VAR00007 & 1.000 & .740 \\
VAR00008 & 1.000 & .778 \\
\hline VAR00009 & 1.000 & .440 \\
VAR00010 & 1.000 & .530 \\
\hline VAR00011 & 1.000 & .710 \\
VAR00012 & 1.000 & .516 \\
\hline VAR00013 & 1.000 & .610 \\
VAR00014 & 1.000 & .631 \\
VAR00015 & 1.000 & .554 \\
VAR00016 & 1.000 & .773 \\
\hline VAR00017 & 1.000 & .482 \\
VAR00018 & 1.000 & .643 \\
VAR00019 & 1.000 & .602 \\
\hline VAR00020 & 1.000 & .637 \\
\hline VAR00022 & 1.000 & .609 \\
VAR00024 & 1.000 & .690 \\
\hline VAR00025 & 1.000 & .652 \\
VAR00026 & 1.000 & .649 \\
\hline
\end{tabular}


In addition, Fig. 1 demonstrates the results of Scree plot, which helps to extract the number of appropriate factors.

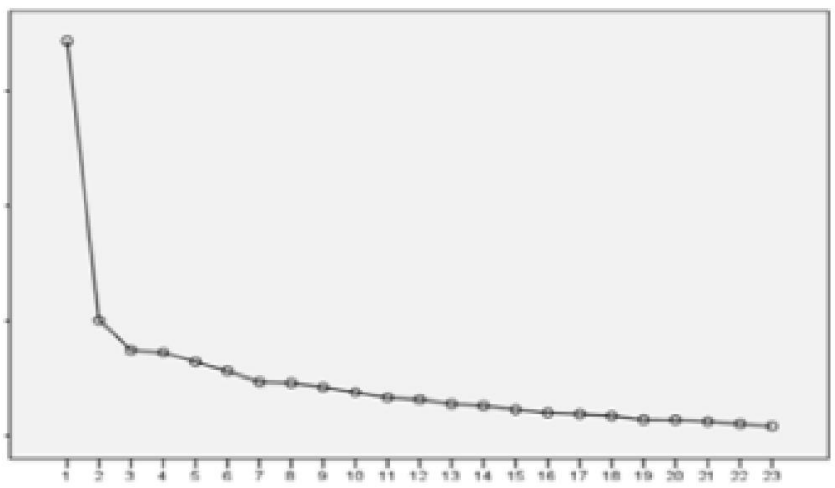

Fig. 1. Scree plot

As we can observe from the results of Scree plot, there are five factors with valid eigenvalue. Table 2 demonstrates the rotated factors extracted from principle component analysis.

Table 2

The summary principle component analysis after rotation

\begin{tabular}{|c|c|c|c|c|c|c|}
\hline & \multicolumn{6}{|c|}{ Component } \\
\hline & 1 & 2 & 3 & 4 & 5 & 6 \\
\hline VAR00024 & .736 & & & & & \\
\hline VAR00022 & .728 & & & & & \\
\hline VAR00026 & .663 & & & & & \\
\hline VAR00013 & .616 & .355 & & & & \\
\hline VAR00011 & & .798 & & & & \\
\hline VAR00014 & & .669 & & & .361 & \\
\hline VAR00012 & & .620 & & & & \\
\hline VAR00010 & .337 & .540 & & & & \\
\hline VAR00002 & .356 & .367 & & & & \\
\hline VAR00003 & & & .798 & & & \\
\hline VAR00008 & & & .779 & & & \\
\hline VAR00020 & .401 & & .513 & & & \\
\hline VAR00005 & & & & .818 & & \\
\hline VAR00001 & & & & .702 & & \\
\hline VAR00025 & .540 & & & .563 & & \\
\hline VAR00009 & & & .390 & .499 & & \\
\hline VAR00006 & & & .346 & .452 & & .331 \\
\hline VAR00016 & & & & & .817 & \\
\hline VAR00018 & & & & & .700 & \\
\hline VAR00015 & & & & & .505 & .372 \\
\hline VAR00017 & .388 & & & & .463 & \\
\hline VAR00007 & & & & & & .849 \\
\hline VAR00019 & .409 & & & & & .523 \\
\hline
\end{tabular}

Based on the results of our survey, we have derived five factors including requirement attributes, proportionality components, consumer choice, product appearance attractiveness and consumer characteristics. Next, we present details of each factor.

\section{The results}

In this section, we present details of our findings associated with each factor through the implementation of principle component analysis. 


\subsection{The first factor: Requirement attributes}

The first factor is associated with requirement attributes and it includes five sub-components summarized in Table 3 as follows,

Table 3

The summary of factors associated with requirement attributes

\begin{tabular}{lcccc}
\hline Option & Factor weight & Eigenvalues & \% of variance & Accumulated \\
\hline Creating purchase decision & 0.735 & & & \\
Convincing drivers & 0.844 & 2.489 & 63.223 & 63.223 \\
Creating motivation & 0.764 & & & \\
Competitive market & 0.720 & & & \\
Product evaluation & 0.664 & & & \\
\hline
\end{tabular}

Cronbach alpha $=0.83$

As we can see from the results of Table 3, convincing drivers is the number one priority on convincing customers followed by creating some good motivation and creating purchasing decision.

\subsection{The second factor: Proportionality components}

The second factor is associated with proportionality components and it includes four sub-components summarized in Table 4 as follows,

\section{Table 4}

The summary of factors associated with proportionality components

\begin{tabular}{lcccc}
\hline Option & Factor weight & Eigenvalues & \% of variance & Accumulated \\
\hline Price of package & 0.748 & & & 56.766 \\
Elasticity to size of package & 0.766 & 2.039 & 56.766 & \\
Favorable assessment of the consumer & 0.720 & & & \\
Expected use of the product & 0.694 & & & \\
\hline Cronbach alpha $=0.67$ & & & &
\end{tabular}

According to the results of Table 4, elasticity to size of package is the number one priority on convincing customers to purchase followed by price of package, favorable assessment of the customer and expected use of the product.

\subsection{The third factor: Customer choice}

The third factor is associated with customer choice and it includes three sub-components summarized in Table 5 as follows,

\section{Table 5}

The summary of factors associated with customer choice

\begin{tabular}{lcccc}
\hline Option & Factor weight & Eigenvalues & \% of variance & Accumulated \\
\hline Visual communication & 0.663 & & & 66.782 \\
Graphic elements & 0.863 & 2.094 & 66.782 & 6 \\
Consumer preferences & 0.798 & & & \\
\hline Cron
\end{tabular}

Cronbach alpha $=0.88$

According to the results of Table 5, Graphical elements are the most important component for convincing customers to purchase followed by consumer preferences and visual communication.

\subsection{The fourth factor: Physical attractiveness}

The fourth factor is associated with physical attractiveness and it includes five sub-components summarized in Table 6 as follows, 
Table 6

The summary of factors associated with Physical attractiveness

\begin{tabular}{lcccc}
\hline Option & Factor weight & Eigenvalues & \% of variance & Accumulated \\
\hline Physical shape of packaging & 0.780 & & & 38.238 \\
Appearance & 0.898 & 1.530 & 38.238 & \\
Promoting product attractiveness & 0.425 & & & \\
Capability of attracting customer & 0.808 & & & \\
Data processing & 0.485 & & & \\
\hline Cronbach alpha $=0.62$ & & &
\end{tabular}

According to the results of Table 6, Appearance is the most important component for convincing customers to purchase followed by Capability of attracting customer, physical shape of packaging, data processing and promoting product attractiveness.

\subsection{The fifth factor: Consumer characteristics}

The fifth factor is associated with consumer characteristics and it includes four sub-components summarized in Table 7 as follows,

Table 7

The summary of factors associated with consumer characteristics

\begin{tabular}{lcccc}
\hline Option & Factor weight & Eigenvalues & \% of variance & Accumulated \\
\hline Educational backgrounds & 0.780 & & & \\
Size of family & 0.898 & 1.530 & 38.238 & 38.238 \\
Family purchase & 0.425 & & & \\
Demand for product & 0.808 & & & \\
\hline Cronbach alpha $=0.69$ & & &
\end{tabular}

According to the results of Table 6, Appearance is the most important component for convincing customers to purchase followed by Capability of attracting customer, physical shape of packaging, data processing and promoting product attractiveness.

\section{Conclusion}

In this paper, we have presented an empirical investigation to find important factors influencing packaging products sold in city of Tehran, Iran. Using principle component analysis, the study has detected five important factors including requirement attributes, proportionality components, consumer choice, product appearance attractiveness and consumer characteristics. In terms of requirement attributes, convincing drivers is the number one priority on convincing customers followed by creating some good motivation and creating purchasing decision. The second factor is associated with proportionality components and it includes four sub-components where elasticity to size of package is the number one priority on convincing customers to purchase followed by price of package, favorable assessment of the customer and expected use of the product.

The third factor, customer choice, includes three sub-components where graphical elements are the most important component for convincing customers to purchase followed by consumer preferences and visual communication. The fourth items is associated with physical attractiveness and it includes five sub-components where Appearance is the most important component for convincing customers to purchase followed by Capability of attracting customer, physical shape of packaging, data processing and promoting product attractiveness. Finally, consumer characteristics is the last item and it includes four sub-components where Appearance is the most important component for convincing customers to purchase followed by Capability of attracting customer, physical shape of packaging, data processing and promoting product attractiveness. 


\section{Acknowledgement}

The authors would like to thank the anonymous referees for the comments made on earlier version of this paper.

\section{References}

Auttarapong, D. (2012). Package design expert system based on relation between packaging and perception of customer. Procedia Engineering, 32, 307-314.

Clement, J., Kristensen, T., \& Grønhaug, K. (2013). Understanding consumers' in-store visual perception: The influence of package design features on visual attention. Journal of Retailing and Consumer Services.

Çakır, M., \& Balagtas, J. V. (2013). Consumer response to package downsizing: Evidence from the Chicago Ice Cream Market. Journal of Retailing.

Giese, J. L., Malkewitz, K., Orth, U. R., \& Henderson, P. W. (2013). Advancing the aesthetic middle principle: Trade-offs in design attractiveness and strength. Journal of Business Research.

Reimann, M., Zaichkowsky, J., Neuhaus, C., Bender, T., \& Weber, B. (2010). Aesthetic package design: A behavioral, neural, and psychological investigation. Journal of Consumer Psychology, 20(4), 431-441.

Schoormans, J. P., \& Robben, H. S. (1997). The effect of new package design on product attention, categorization and evaluation. Journal of Economic Psychology, 18(2), 271-287. 